\title{
THE IMPACT OF AUTHENTIC LEADERSHIP ON EMPLOYEE PSYCHOLOGICAL CAPITAL IN THE HOSPITALITY INDUSTRY*
}

\author{
Sanda Grudić Kvasić1 ${ }^{\text {, Gordana Nikolić }}{ }^{\text {\& Vedran }}$ Milojica $^{3}$
}

UDC / UDK: 658:159.923:640.4

JEL classification / JEL klasifikacija: C12, L20, L83

DOI: https://doi.org/10.22598/pi-be/2021.15.1.9

Original scientific paper / Izvorni znanstveni rad

Received / Primljeno: September 17, 2020 / 17. rujna 2020.

Accepted for publishing / Prihvaćeno za tisak: April 12, 2021 / 12. travnja 2021.

\section{Summary}

Psychological capital is a focal component of authentic leadership theory. The importance and growing popularity of psychological capital stem from its positive effect on desirable employee work-related attitudes and behaviors, which is particularly pronounced in the service industries. However, empirical research on the relationship between authentic leadership and psychological capital in the hospitality industry is scarce. In order to fulfil this gap in the literature, the present study investigates the influence of authentic leadership on hotel employees' psychological capital, additionally examining the moderating role of organizational structure. Hypotheses were tested using hierarchical multiple regression analysis on a sample of 226 employees from 24 hotels in Croatia. The findings confirmed that managers who demonstrate authentic leadership behaviors are able to positively impact hotel employees' psychological capacities of hope, optimism, resilience and self-efficacy. However, there was no empirical evidence to support the hypothesized moderation effect of organic organizational structures in the said relationship.

Keywords: authentic leadership; psychological capital; hospitality industry; positive organizational behavior.

* This paper is based on the doctoral thesis titled "The Impact of Leadership on Organisational Performance in the Hospitality Industry" written by Sanda Grudić Kvasić (https://repository.efri.uniri.hr/islandora/object/efri:1228)

${ }^{1}$ Sanda Grudić Kvasić, PhD, Lecturer, PAR University College, Trg Riječke rezolucije 4, 51000 Rijeka, Croatia, E-mail: sanda.kvasic@par.hr

${ }^{2}$ Gordana Nikolić, PhD, Assistant Professor, PAR University College, Trg Riječke rezolucije 4, 51000 Rijeka, Croatia, E-mail: gnikolic@par.hr

${ }^{3}$ Vedran Milojica, M.A., PAR University College, Trg Riječke rezolucije 4, Rijeka, Croatia, E-mail: vedran.milojica@par.hr 


\section{INTRODUCTION}

Empirical research on the relationship between authentic leadership and psychological capital in the hospitality industry is scarce. In order to fulfil this gap in the literature, the present study investigates the impact of authentic leadership on hotel employees' psychological capital, additionally examining the moderating role of organizational structure.

Authentic leadership (AL) is now a well-known and established form of positive, transparent and ethical organizational leadership that can meet today's economic and wider societal challenges. In the theory-building process, scholars drew from positive psychology (Seligman \& Csikszentmihalyi, 2000) and positive organizational behavior (POB) movement (Luthans, Avolio, Avey \& Norman, 2007) in order to describe the mechanisms by which authentic leaders exert their influence on followers' attitudes and behaviors.

As a prominent construct in POB, psychological capital (PsyCap) - comprised of hope, optimism, resilience and self-efficacy, was found to be an important antecedent as well as a consequence of authentic leadership. Namely, the leader's psychological resources were set to encourage the development of authentic leadership which, through influential processes of personal identification and positive modeling, results in a higher level of psychological capital and authenticity of followers (Avolio \& Gardner, 2005; Gardner, Avolio, Luthans, May \& Walumbwa, 2005; Ilies, Morgeson \& Nahrgang, 2005; Walumbwa, Avolio, Gardner, Wernsing \& Peterson, 2008).

The relevance of PsyCap is reflected in a plethora of empirical studies proving its positive impact on desirable employee work-related attitudes and behaviors, such as job satisfaction, organizational citizenship behavior and job performance (Cerović \& Grudić Kvasić, 2016). It is important to note that this effect is particularly pronounced in the service industries (Avey et al., 2011) that are based on social interactions in which the expression of employees' positive cognitive and affective states is expected (Pugh, 2001).

In hospitality organizations, as is any labor-intensive industry, the achievement of business objectives and competitiveness is largely dependent on employees' performance (Ottenbacher, 2007). This stems from the fundamental characteristic of services, that is the impossibility of separating the service from the service provider (Wirtz, Heracleous \& Pangarkar, 2008). According to the Service-Profit-Chain theoretical framework (Sasser, Schlesinger \& Heskett, 1997), service employees, and especially frontline employees, drive customer satisfaction and loyalty and, consequently, organizations' growth and profitability. As a result, a growing number of scholars point out that employees should be at the center of hospitality management research (Hofmann \& Stokburger-Sauer, 2017; Lu \& Gursoy, 2016; Slåtten, Svensson \& Sværi, 2011).

So far, the relationship between authentic leadership and psychological capital has been empirically tested in numerous settings: nursing (Laschinger \& Fida, 2014), commerce (Rego, Sousa, Marques \& Cunha, 2012), logistics (Wang, Sui, Luthans, Wang \& Wu, 2014), education (Adil \& Kamal, 2016), maritime and airline industry (Avey, 2014; Hystad, Bartone \& Eid, 2014; Olaniyan \& Hystad, 2016). Yet, similar work in the hospitality industry is scarce (Schuckert, Kim, Paek \& Lee, 2018). Also, even though the 
initial AL model posits that authentic leadership develops under "a highly developed organizational context" (Luthans \& Avolio, 2003: 243), this is the subject of only a few empirical studies.

Building upon earlier research, this study examines the influence of authentic leaders on employees' psychological capital in the hospitality domain. The authors suggest that such an impact is more significant in organizations with flexible organizational structures. In testing the proposed hypotheses, the authors employ a quantitative positivistic research design. The level of analysis is the individual employee. In the following literature review segment, a more detailed definition of the aforementioned theoretical frameworks is provided.

\section{LITERATURE REVIEW}

\section{Psychological capital}

The inception of positive organizational behavior indicated a paradigm shift in terms of moving away from the study of "negativity", i.e organizational irregularities and deficiencies, and instead, focusing on positive individual outcomes that contribute to the achievement of organizational goals in a globalized and uncertain business environment. While it recognized the value of positive constructs traditionally researched in the field of organizational behavior, the school of positive organizational behavior introduced a new concept called "psychological capital".

As a core construct of POB, psychological capital meets the following inclusion criteria (Luthans et al., 2007: 8; Luthans, 2010: 199): (1) Based on theory and research: as opposed to popular self-help literature on positivity, psychological capital is founded in renewed theoretical frameworks such as social cognitive theory; (2) Valid measurement: most widely used measures of PsyCap are the 24-item Psychological Capital Questionnaire (Luthans et al., 2007), the 12-item PCQ (Luthans, Avey, Smith \& Li, 2008), and the implicit measure I-PCQ (Harms \& Luthans, 2012); (3) State-like: PsyCap is readily open and malleable to development and change as opposed to fixed traits.; (4) Impactful on work-related performance: conceptual and empirical research supports the fact that psychological capital is positively and significantly related to employee performance in the workplace.

Luthans et al. (2007: 3) describe psychological capital as an "individual's positive psychological state of development and is characterized by a) having confidence (self-efficacy) to take on and put in the necessary effort to succeed at challenging tasks; b) making a positive attribution (optimism) about succeeding now and in the future; c) persevering toward goals and, when necessary, redirecting paths to goals (hope) in order to succeed; and d) when beset by problems and adversity, sustaining and bouncing back and even beyond (resilience) to attain success".

\section{Authentic leadership}

Several years after the concept of PsyCap had been introduced in the literature, a question of whether leaders impact their followers' psychological capital was raised. 
Answering this scholarly call, a positive relationship between the leader's and employees' psychological capital has been established in the work of authors mainly interested in the theory of authentic leadership.

Authentic leadership is a contemporary leadership theory which emerged in response to corporate ethical scandal and societal upheavals at the turn of the century. Conceptualized as a "root construct" underlying all positive forms of leadership (Gardner et al., 2005), AL was set to restore trust among followers and to promote their well-being and development. Authentic leaders are perceived by others as being aware of their own and others' values, knowledge, and strengths; aware of the context in which they operate; and who are confident, hopeful, resilient, and of high moral character (Avolio, Gardner, Walumbwa, Luthans \& May, 2004). In addition to the individual authenticity of the leader, authentic leadership also encompasses the authenticity of the relationship between leaders and followers which is characterized by transparency, openness and trust, as well as the promotion of personal and professional development of followers (Gardner et al., 2005).

AL was first defined as "a process that draws from both positive psychological capacities and a highly developed organizational context, which results in both greater self-awareness and self-regulated positive behaviors on the part of leaders and associates, fostering positive self-development" (Luthans \& Avolio, 2003). The authentic leader is confident, hopeful, optimistic, resilient, transparent, moral/ethical future-oriented, and gives priority to developing associates into leaders themselves. Psychological capital is thus posited as both an input and an outcome of authentic leadership development. Namely, authentic leaders draw from their own positive psychological states that accompany optimal self-esteem and psychological well-being, such as confidence, optimism, hope and resilience, to model and promote the development of these states in others (followers).

The presumed influence of authentic leadership on employee psychological capital is supported by several theoretical considerations, with an emphasis on the process of personal identification and leading by example. Avolio et al. (2004) suggest that the personal identification of the follower with the leader is encouraged through leading by example and by expressing high moral standards, honesty and integrity of the leader in mutual interactions. Their study further explains how authentic leaders have the ability to maintain hope and trust and thus foster hope in followers by not only strengthening their willpower, but also providing them with guidelines for action. This also increases their sense of self-efficacy. Furthermore, authentic leaders take a positive stance in interpreting information, events, and interactions with followers, and thus increase their optimism.

Finally, and in line with integrative approach to leadership, many scholars raised the issue of contextual factors that need to be addressed in the authentic leadership research. As Gardner (1993: 1) asserted, leaders "are an integral part of the system, subject to the forces that affect the system... In the process, leaders shape and are shaped". Avolio et al. (2004) emphasized the role of organizational power, organizational structure and culture as contextual factors that may influence the authentic leadership process, while Jensen \& Luthans (2006) associated the effectiveness of authentic leadership with an organic organizational structure. Investigating the relationship between authentic 
leadership and followers' psychological capital, Woolley, Caza \& Levy (2011) identified a positive organizational climate as the mediation variable. Similar research has not been conducted in the hospitality industry.

Based on the discussion presented so far, the authors propose the following hypotheses: capital.

H1: Authentic leadership is positively related to employees' psychological

H2: Organic organizational structure moderates the relationship between authentic leadership and employees' psychological capital.

\section{METHODOLOGY}

\section{Sample and procedure}

Data analysis was performed on a sample of 226 hotel employees from 24 two, three-, four- and five-star hotels located in three different destinations in Croatia. The respondents were predominately female (59.30 percent) and with secondary education (58.40 percent). The mean age was 36.5 years $(\mathrm{SD}=8.5)$. On average, employees had 8.9 years of organizational tenure $(\mathrm{SD}=3.7)$. Hotel employees were asked to rate their leader's AL behaviors and hotel's organizational structure, while PsyCap was measured through employees' self-report.

\section{Measures}

The Authentic Leadership Inventory - ALI (Neider \& Schriesheim, 2011) was used to measure hotel employees' perception of their manager's authentic leadership behavior. It consists of 16 items (four items four each AL dimensions: self-awareness, relational transparency, internalized moral perspective and balanced processing). Sample items for each dimension are the following: (1) Self-awareness: "My leader shows that he/she understands his/her strengths and weaknesses"; (2) Relational transparency: "My leader clearly states what he/she means"; (3) Internalized moral perspective: "My leader resists pressures on him/her to do things contrary to his/her beliefs"; (4) Balanced processing: "My leader carefully listens to alternative perspectives before reaching a conclusion".

The 24-item Psychological Capital Questionnaire - PCQ (Luthans et al., 2007) was used to assess employees' psychological capital. The scale utilizes six items for each dimension of psychological capital (self-efficacy, hope, optimism, resilience). Sample items are the following: (1) Self-efficacy: "I feel comfortable in representing my work area in meetings with management"; (2) Hope: "I can think of many ways to reach my current goals"; (3) Optimism: "I'm optimistic about what will happen to me in the future as it pertains to work"; (4) Resilience: "I can get through difficult times at work because I've experienced difficulty before". In order to maintain a consistent positive direction of responses, three items $(13,20$ and 23) were reversed coded prior to analysis, which is in line with procedures in similar research (Avey, Nimnicht \& Pigeon, 2010). Generally speaking, negatively worded items have proven to be problematic in previous research on 
positive constructs (Merritt, 2012). A sample item of a negatively worded item (13) is: "When I have a setback at work, I have a hard time recovering from it, moving on".

The organizational structure is commonly operationalized using its different key variables: complexity (vertical and horizontal differentiation), formalization, and centralization (Baligh, 2006: 4). Given the nature of the present research where the organizational structure is primarily related to leadership and employee attitudes, the examination of organizational structure is based on evaluating formalization - as the degree to which decision making and behavior at work is determined by rules, policies and procedures (Pugh, Hickson, Hinings \& Turner, 1968), and according to which organizations are commonly divided into mechanical (bureaucratic) and organic (Burns \& Stalker, 1961; Woodward, 1958). The level of formalization is measured with a 3 -item instrument (Olson, Slater \& Hult, 2005). A sample item is: "There is little action taken unless the decision fits with standard operating procedures". Responses were reported on a five-point Likert scale ( 1 = "strongly disagree", 5 = "strongly agree").

\section{Data analysis}

In addition to descriptive statistics, reliability and correlation analysis, the hypothesis was tested using hierarchical multiple regression analysis. The level of analysis is the individual employee. Data analysis was conducted using the Statistical package for the social sciences (SPSS 23.0).

\section{RESULTS}

\section{Descriptives}

Both AL and PsyCap demonstrated adequate internal reliability, yielding Cronbach alphas which are well above the benchmark (.992 for AL and .896 for PsyCap). Although the organizational structure scale (.631) did not reach the generally acceptable level of internal consistency, it can still be considered as a marginally acceptable reliability (Hair, Anderson, Babin \& Black, 2010).

The descriptive statistics for main study variables (Table 1) revealed a relatively high level of authentic leadership $(\mathrm{M}=3.81)$ and employees' psychological capital $(\mathrm{M}=$ 3.88). The hotel's organizational structure is perceived as moderately formalized $(\mathrm{M}=$ 3.14), which indicates moderate levels of centralization and employees' autonomy.

Table 1. Descriptive statistics and correlations for main study variables

\begin{tabular}{lrrrrrrrr}
\hline Gender & $.41(.49)$ & & & & & & & \\
Age & $36.47(8.52)$ & .103 & & & & & & \\
Tenure & $8.95(3.74)$ & .125 & .120 & & & & & \\
Education & $1.73(.90)$ & $.152^{*}$ & $-.146^{*}$ & .043 & & & \\
OS & $3.14(.87)$ & .097 & .007 & $.135^{*}$ & .002 & .631 & & \\
AL & $3.81(.52)$ & -.015 & -.038 & -.103 & .075 & $.333^{* *}$ & $\mathbf{. 9 9 2}$ & \\
PC & $3.88(.51)$ & -.044 & -.128 & $-.176^{* *}$ & $.203^{* *}$ & $.245^{* *}$ & $.389^{* *}$ & $\mathbf{. 8 9 6}$ \\
\hline
\end{tabular}

Note: $\mathrm{OS}=$ organizational structure, $\mathrm{AL}=$ authentic leadership, $\mathrm{PC}=$ psychological capital. Scale reliabilities appear in bold. $* \mathrm{p}<.05, * * \mathrm{p}<.01$. 
Using Cohen's (1988) effect size criterion, small correlations were found between employees' gender and education $(\mathrm{r}=.152, \mathrm{p}<.05)$, employees' age and education $(\mathrm{r}=-.146, \mathrm{p}<.05)$, employees' tenure and hotel's organic organizational structure $(\mathrm{r}=.135, \mathrm{p}<.05)$, employees' tenure and PsyCap $(\mathrm{r}=.176, \mathrm{p}<.01)$, employees' education and PsyCap $(\mathrm{r}=.203, \mathrm{p}<.01$, ) and organic organizational structure and employees' PsyCap $(\mathrm{r}=.245, \mathrm{p}<.01)$. Medium correlations were only established between organic organizational structure and AL $(\mathrm{r}=.335, \mathrm{p}<.01)$, and AL and PsyCap $(\mathrm{r}=.389, \mathrm{p}<.01)$.

\section{Hypotheses testing}

The first hypothesis, predicting a direct impact of perceived authentic leadership on employees' psychological capital, was tested using hierarchical multiple regression analysis where the control variables of employees' gender, age, tenure and education were entered into Step 1 and AL into Step 2.

Table 2. The direct effect of authentic leadership on employees' psychological capital

\begin{tabular}{lcc}
\hline & Psychological capital & \\
\hline & Step 1 & Step 2 \\
\hline Gender & $\beta$ & $\beta$ \\
Age & -.027 & -.022 \\
Tenure & -.093 & -.087 \\
High school vs. Bachelor & $-.167^{*}$ & $-.129 *$ \\
High school vs. Master & .057 & .038 \\
Authentic leadership & .089 & .065 \\
$\mathrm{R}^{2}$ & & $.367^{* *}$ \\
$\Delta \mathrm{R}^{2}$ & .052 & .184 \\
$\Delta \mathrm{F}$ & .052 & .133 \\
\hline
\end{tabular}

Note: Standardized coefficients reported: $* p<.05, * * p<.01$.

As seen in Table 2, entering authentic leadership in Step 2 predicted significant variance beyond the covariates $\left(\mathrm{R}^{2}=.184\right)$. More specifically, the $\mathrm{R}^{2}$ change associated with $\mathrm{AL}$ is significant $(\Delta \mathrm{F}=35.583, \mathrm{p}<.01)$, thus showing full support for Hypothesis 1 $(\beta=.367, \mathrm{p}<.01)$.

Table 3. Results of moderation analysis

\begin{tabular}{lccccc}
\hline Predictor & Beta & Sig. & $\mathbf{R}^{2}$ & F & Sig. \\
\hline $\mathrm{AL}$ & .345 & .000 & .167 & 14.785 & 0,000 \\
$\mathrm{OS}$ & .128 & .051 & & & \\
$\mathrm{AL} \mathrm{c}^{*} \mathrm{OS} \mathrm{c}$ & -.023 & .713 & & & \\
\hline
\end{tabular}

Dependent variable: psychological capital

For the second hypothesis, which indicated that organizational structure affects the strength of the relationship between authentic leadership and employee psychological capital, we followed the moderation procedure outlined by Dawson (2014). 
Since the results of the moderation regression analysis (Table 3) showed that there is no statistically significant moderator effect of hotel's organizational structure $(\beta$ $=-.023 ; \mathrm{p}=0.713)$, Hypothesis 2 was not supported.

\section{DISCUSSION}

The results of multiple regression analysis have validated the hypothesis $(H 1)$ predicting a positive impact of authentic leadership on employees' psychological capital $(\beta=.367, \mathrm{p}<.01)$. This is in line with previous research (Schuckert et al., 2018), which demonstrated that authentic leadership has a greater effect on hotel employees' PsyCap than transformational leadership.

In contrast, the findings did not support the hypothesized moderating effect of flexible organizational structure (H2) in the relationship between AL and hotel employees' PsyCap $(\beta=.023 ; \mathrm{p}=0.713)$. Considering the significant correlations between both organic organizational structure and employees' PsyCap $(r=.245, p<.01)$, and organic organizational structure and $\operatorname{AL~}(\mathrm{r}=.335, \mathrm{p}<.01)$, one possible explanation for this result may be that organizational structure in fact mediates the observed relationship.

\section{Implications}

This study has both theoretical and managerial implications. Firstly, the study replicates previous research by confirming the positive influence of authentic leadership on employees' psychological capital. Furthermore, by testing the moderated impact of AL on employee PsyCap in the Croatian hospitality industry, the study answers recent scholarly calls for examining AL effects in different cultural and organizational contexts, and for introducing variables which help clarify the processes underlying the phenomenon.

On the managerial side, the study shows that PsyCap is a significant motivational propensity leading to desired performance outcomes, which justifies the organizational efforts in developing and enhancing employees' levels of hope, optimism, resilience and self-efficacy. The literature provides evidence of elevated PsyCap levels through Psychological Capital Intervention (Luthans, Avey, Avolio, Norman \& Combs, 2006; Luthans et al., 2008; Luthans, Avey, Avolio \& Peterson, 2010) and authentic leadership development (see meta-analysis by Banks, McCauley, Gardner \& Guler, 2016; Hoch, Bommer, Dulebohn \& Wu, 2018). Although AL emerged in response to economic and social upheavals at the turn of the 21 st century, the need for authentic, moral and bona fide leaders remains as strong now as it was then.

\section{Limitations}

The results of this study should be evaluated with the following limitations. Firstly, the research was cross sectional in nature, and therefore a case could be made for reverse causality (that in fact employees' PsyCap enhances managers' authentic leadership behaviors). The second limitation concerns the common-source bias 
(Podsakoff, MacKenzie, Lee \& Podsakoff, 2003) as all data regarding authentic leadership, psychological capital and organizational structure came from the same source (employees).

However, 'in defense' of such methodological choices, it should be noted that the use of multiple sources is not possible in cases where individual attitudes and personal (psychological) characteristics are measured (Podsakoff et al., 2003: 887). Likewise, previous research (Černe, Jaklič \& Škerlavaj, 2013) has shown that only the perception of followers about the authenticity of leadership, and not the assessment of the leader himself, affects the attitudes of employees.

\section{CONCLUSION}

Despite the fact that the interest in the relationship between authentic leadership and psychological capital is increasing over time, the said relationship is somewhat neglected in the hospitality literature. Therefore, the purpose of the study was to test a model linking authentic leadership to employees' psychological capital in the hospitality settings. The findings confirmed that managers who demonstrate authentic leadership behaviors are able to positively impact hotel employees' psychological capacities of hope, optimism, resilience and self-efficacy. However, there was no empirical evidence to support the hypothesized moderation effect of organic organizational structures in the said relationship. The level of analysis was the individual employee.

However, following the example of the procedures undertaken in similar studies (Paek, Schuckert, Kim \& Lee, 2015; Schuckert et al., 2018), future research should involve administering questionnaires in separate time frames, along with undertaking longitudinal designs which enable a better explication of the nature of AL-PsyCap relationship are highly recommended.

Finally, since authentic leadership is a multi-faceted construct, future research should include the examination of the impact of authentic leadership on psychological capital on different level of analysis (individual, group and organizational), utilizing hierarchical linear modelling (HLM). Also, a mixed method study which would include a qualitative phase may be incorporated into future studies to further clarify the relationships among the main variables.

\section{REFERENCES:}

1. Adil, A., \& Kamal, A. (2016). Impact of psychological capital and authentic leadership on work engagement and job-related affective well-being. Pakistan Journal of Psychological Research, 31(1), 1-21.

2. Avey, J. B. (2014). The left side of psychological capital: New evidence on the antecedents of PsyCap. Journal of Leadership \& Organizational Studies, 21(2), 141-149. https://doi.org/10.1177\%2F1548051813515516 
3. Avey, J. B., Nimnicht, J. L., \& Pigeon, N. G. (2010). Two field studies examining the association between positive psychological capital and employee performance. Leadership \& Organization Development Journal, 31(5), 384-401. https://doi.org/10.1108/01437731011056425

4. Avey, J. B., Reichard, R. J., Luthans, F., \& Mhatre, K. H. (2011). Metaanalysis of the impact of positive psychological capital on employee attitudes, behaviors, and performance. Human resource development quarterly, 22(2), 127-152. https://psycnet.apa.org/doi/10.1002/hrdq.20070

5. Avolio, B. J., \& Gardner, W. L. (2005). Authentic leadership development: Getting to the root of positive forms of leadership. The leadership quarterly, 16(3), 315-338. https://doi.org/10.1016/j.leaqua.2005.03.001

6. Avolio, B. J., Gardner, W. L., Walumbwa, F. O., Luthans, F., \& May, D. R. (2004). Unlocking the mask: A look at the process by which authentic leaders impact follower attitudes and behaviors. The leadership quarterly, 15(6), 801823. https://doi.org/10.1016/j.leaqua.2004.09.003

7. Baligh, H. H. (2006) Organization structures. in: Baligh, H.H. , Ed., Organization Structures Theory and Design, Analysis and Prescription. United States of America: Springer US, pp. 33-64.

8. Banks, G. C., McCauley, K. D., Gardner, W. L., \& Guler, C. E. (2016). A meta-analytic review of authentic and transformational leadership: A test for redundancy. The leadership quarterly, 27(4), 634-652. https://doi.org/10.1016/j.leaqua.2016.02.006

9. Burns, T. and Stalker, G.M. (1961) The Management of Innovation. London: Social Science Paperbacks/Tavistock Publications.

10. Černe, M., Jaklič, M., \& Škerlavaj, M. (2013). Authentic leadership, creativity, and innovation: A multilevel perspective. Leadership, 9(1), 63-85. https://doi.org/10.1177\%2F1742715012455130

11. Cerovic, Z., \& Kvasic, S. G. (2016, June). Managing employees' psychological capital. In An Enterprise Odyssey. International Conference Proceedings ( $\mathrm{p}$. 49). University of Zagreb, Faculty of Economics and Business.

12. Cohen, J. (1988). Statistical power analysis for the behavioral sciences, 2nd ed. Hillsdale, NJ: Erlbaum.

13. Dawson, J. F. (2014). Moderation in management research: What, why, when, and how. Journal of business and psychology, 29(1), 1-19. https://doi.org/10.1007/s10869-013-9308-7

14. Gardner, J., \& Gardner, J. W. (1993). On leadership. New York: The Free Press.

15. Gardner, W. L., Avolio, B. J., Luthans, F., May, D. R., \& Walumbwa, F. (2005). Can you see the real me?" A self-based model of authentic leader and follower development. The Leadership Quarterly, 16(3), 343-372. https://doi.org/10.1016/j.leaqua.2005.03.003

16. Hair, J. F., Anderson, R. E., Babin, B. J., \& Black, W. C. (2010). Multivariate data analysis: A global perspective (Vol. 7). 
17. Harms, P. D., \& Luthans, F. (2012). Measuring implicit psychological constructs in organizational behavior: An example using psychological capital. Journal of Organizational Behavior, 33(4), 589-594. https://doi.org/10.1002/job.1785

18. Hoch, J. E., Bommer, W. H., Dulebohn, J. H., \& Wu, D. (2018). Do ethical, authentic, and servant leadership explain variance above and beyond transformational leadership? A meta-analysis. Journal of Management, 44(2), 501-529. https://doi.org/10.1177\%2F0149206316665461

19. Hofmann, V., \& Stokburger-Sauer, N. E. (2017). The impact of emotional labor on employees' work-life balance perception and commitment: A study in the hospitality industry. International Journal of Hospitality Management, 65, 47-58. https://doi.org/10.1016/j.ijhm.2017.06.003

20. Hystad, S. W., Bartone, P. T., \& Eid, J. (2014). Positive organizational behavior and safety in the offshore oil industry: Exploring the determinants of positive safety climate. The journal of positive psychology, 9(1), 42-53. https://dx.doi.org/10.1080\%2F17439760.2013.831467

21. Ilies, R., Morgeson, F. P., \& Nahrgang, J. D. (2005). Authentic leadership and eudaemonic well-being: Understanding leader-follower outcomes. The leadership quarterly, 16(3), 373-394. https://doi.org/10.1016/j.leaqua.2005.03.002

22. Jensen, S. M., \& Luthans, F. (2006). Entrepreneurs as authentic leaders: Impact on employees' attitudes. Leadership \& Organization Development Journal, 27(8), 646-666. https://doi.org/10.1108/01437730610709273

23. Laschinger, H. K. S., \& Fida, R. (2014). New nurses burnout and workplace wellbeing: The influence of authentic leadership and psychological capital. Burnout Research, 1(1), 19-28. https://doi.org/10.1016/j.burn.2014.03.002

24. Lu, A. C. C., \& Gursoy, D. (2016). Impact of job burnout on satisfaction and turnover intention: do generational differences matter?. Journal of Hospitality \& Tourism Research, 40(2), 210-235. https://doi.org/10.1177\%2F1096348013495696

25. Luthans, F., \& Avolio, B. (2003). Authentic leadership development. In K. S. Cameron, S. E. Dutton, \& R. E. Quinn (Eds.), Positive organizational scholarship_Foundations of a new discipline (pp. 241-258). San Francisco, CA: Berrett-Koehler.

26. Luthans, F., Avey, J. B., Avolio, B. J., \& Peterson, S. J. (2010). The development and resulting performance impact of positive psychological capital. Human resource development quarterly, 21(1), 41-67. https://doi.org/10.1002/hrdq.20034

27. Luthans, F., Avey, J. B., Avolio, B. J., Norman, S. M., \& Combs, G. M. (2006). Psychological capital development: toward a microintervention. Journal of Organizational Behavior: The International Journal of Industrial, Occupational and Organizational Psychology and Behavior, 27(3), 387-393. https://doi.org/10.1002/job.373 
28. Luthans, F., Avey, J. B., Clapp-Smith, R., \& Li, W. (2008). More evidence on the value of Chinese workers' psychological capital: A potentially unlimited competitive resource?. The International Journal of Human Resource Management, 19(5), 818-827. https://doi.org/10.1080/09585190801991194

29. Luthans, F., Avolio, B. J., Avey, J. B., \& Norman, S. M. (2007). Positive psychological capital: Measurement and relationship with performance and satisfaction. Personnel psychology, 60(3), 541-572. https://psycnet.apa.org/doi/10.1111/j.1744-6570.2007.00083.x

30. Luthans, F., Youssef, C. M., \& Avolio, B. J. (2007). Psychological capital: Investing and developing positive organizational behavior. In Nelson, D.L. \& Cooper, G.L. (Eds.), Positive Organizational Behavior (pp. 9-24). California, United States of America: SAGE Publications Ltd. http://dx.doi.org/10.4135/9781446212752.n2

31. Merritt, S. M. (2012). The two-factor solution to Allen and Meyer's (1990) affective commitment scale: Effects of negatively worded items. Journal of Business and Psychology, 27, 421-436. https://doi.org/10.1007/s10869-0119252-3

32. Neider, L. L., \& Schriesheim, C. A. (2011). The authentic leadership inventory (ALI): Development and empirical tests. The leadership quarterly, 22(6), 1146-1164. https://doi.org/10.1016/j.leaqua.2011.09.008

33. Olaniyan, O. S., \& Hystad, S. W. (2016). Employees' psychological capital, job satisfaction, insecurity, and intentions to quit: The direct and indirect effects of authentic leadership. Revista de Psicología del Trabajo y de las Organizaciones, 32(3), 163-171. https://doi.org/10.1016/j.rpto.2016.09.003

34. Olson, E. M., Slater, S. F., \& Hult, G. T. M. (2005). The Performance Implications of Fit among Business Strategy, Marketing Organization Structure, and Strategic Behavior. Journal of marketing, 69(3), 49-65. https://doi.org/10.1509\%2Fjmkg.69.3.49.66362

35. Ottenbacher, M. C. (2007). Innovation management in the hospitality industry: different strategies for achieving success. Journal of hospitality \& tourism research, 31(4), 431-454. https://doi.org/10.1177\%2F1096348007302352

36. Paek, S., Schuckert, M., Kim, T. T., \& Lee, G. (2015). Why is hospitality employees' psychological capital important? The effects of psychological capital on work engagement and employee morale. International journal of hospitality management, 50, 9-26. https://doi.org/10.1016/j.ijhm.2015.07.001

37. Podsakoff, P. M., MacKenzie, S. B., Lee, J. Y., \& Podsakoff, N. P. (2003). Common method biases in behavioral research: a critical review of the literature and recommended remedies. Journal of applied psychology, 88(5), 879-903. https://psycnet.apa.org/doi/10.1037/0021-9010.88.5.879

38. Pugh, D. S., Hickson, D. J., Hinings, C. R., \& Turner, C. (1968). Dimensions of organization structure. Administrative science quarterly, 13(1), 65-105. https://doi.org/10.2307/2391262 
39. Pugh, S. D. (2001). Service with a smile: Emotional contagion in the service encounter. Academy of management journal, 44(5), 1018-1027. https://doi.org/10.5465/3069445

40. Rego, A., Sousa, F., Marques, C., \& e Cunha, M. P. (2012). Authentic leadership promoting employees' psychological capital and creativity. Journal of business research, 65(3), 429-437. https://doi.org/10.1016/j.jbusres.2011.10.003

41. Sasser, W. E., Schlesinger, L. A., \& Heskett, J. L. (1997). The Service profit chain. New York: The Fine Press.

42. Schuckert, M., Kim, T. T., Paek, S., \& Lee, G. (2018). Motivate to innovate: How authentic and transformational leaders influence employees' psychological capital and service innovation behavior. International Journal of Contemporary Hospitality Management, 30(2), 776-796. https://doi.org/10.1108/IJCHM-05-2016-0282

43. Seligman, M. E. P. \& Csikszentmihalyi, M. (2000). Positive psychology: An introduction. American Psychologist, 55(1), 5-14. https://psycnet.apa.org/doi/10.1037/0003-066X.55.1.5

44. Slåtten, T., Svensson, G., \& Sværi, S. (2011). Empowering leadership and the influence of a humorous work climate on service employees' creativity and innovative behaviour in frontline service jobs. International Journal of Quality and Service Sciences, 3(3), 267-284. https://doi.org/10.1108/17566691111182834

45. Walumbwa, F. O., Avolio, B. J., Gardner, W. L., Wernsing, T. S., \& Peterson, S. J. (2008). Authentic leadership: Development and validation of a theorybased measure. Journal of management, 34(1), 89-126. https://doi.org/10.1177\%2F0149206307308913

46. Wang, H., Sui, Y., Luthans, F., Wang, D., \& Wu, Y. (2014). Impact of authentic leadership on performance: Role of followers' positive psychological capital and relational processes. Journal of Organizational Behavior, 35(1), 5 21. https://doi.org/10.1002/job.1850

47. Wirtz, J., Heracleous, L., \& Pangarkar, N. (2008). Managing human resources for service excellence and cost effectiveness at Singapore Airlines. Managing Service Quality: An International Journal, 18(1), 4-19. https://doi.org/10.1108/09604520810842812

48. Woodward, J. (1958). Management and technology (No. 3). HM Stationery Off.

49. Woolley, L., Caza, A., \& Levy, L. (2011). Authentic leadership and follower development: Psychological capital, positive work climate, and gender. Journal of Leadership \& Organizational Studies, 18(4), 438-448. https://doi.org/10.1177\%2F1548051810382013 


\title{
UTJECAJ AUTENTIČNOG VODSTVA NA PSIHOLOŠKI KAPITAL ZAPOSLENIKA U UGOSTITELJSTVU
}

\author{
Sanda Grudić Kvasić, Gordana Nikolić \& Vedran Milojica
}

\section{Sažetak}

Psihološki kapital se smatra okosnicom teorije autentičnog vodstva. Važnost $i$ rastuća popularnost psihološkog kapitala proizlaze iz njegovog pozitivnog učinka na poželjne stavove $i$ ponašanja zaposlenika, što je posebno izraženo u uslužnim djelatnostima. Međutim, empirijska istraživanja odnosa između autentičnog vodstva $i$ psihološkog kapitala u ugostiteljstvu su malobrojna. U tom smislu, ova studija istražuje utjecaj autentičnog vodstva na psihološki kapital hotelskih zaposlenika, dodatno ispitujući moderirajuću ulogu organizacijske strukture. Testiranje hipoteza rada je izvršeno primjenom hijerarhijske višestruke regresijske analize na uzorku od 226 anketnih upitnika, prikupljenih u 24 hotela na području Republike Hrvatske. Rezultati istraživanja su potvrdili da menadžeri koji demonstriraju autentično ponašanje mogu pozitivno utjecati na psihološke sposobnosti nade, optimizma, otpornosti $i$ samoefikasnosti zaposlenika u hotelima. S druge strane, pretpostavljeni moderirajući učinak organskih organizacijskih struktura u spomenutom odnosu nije potvrđen.

Ključne riječi: autentično vodstvo; psihološki kapital; ugostiteljstvo; pozitivno organizacijsko ponašanje. 